\title{
Medical and Legal Constraints for Organizing 2020 Regional Head Election in the Covid-19 Pandemic in Indonesia
}

\author{
Sri Wahyu Ananingsih', Ratna Dewi Pettalolo² \\ ${ }^{1}$ Lecturer at Universitas Diponegoro, ${ }^{2}$ Lecturer at Universitas Tadulako
}

\begin{abstract}
In 2020, Indonesia will hold regional head elections simultaneously in 270 regions covering 9 provinces, 224 districts and 37 cities, voting on 9 December 2020. This study aims to analyse the potential for general elections in the midst of Covid-19 pandemic in Indonesia...Descriptive qualitative research method are used in which the data is obtained through interactive discussions, interviews and document searches. The results of our analysis conclude that there are 4 potential vulnerabilities in the 2020 elections, namely the availability of the budget, the readiness of election organizers, the number of alleged violations and the level of community participation. Recommendations for this study are the efforts to collaborate, coordinate and communicate well between the government and the election organizer and increase public participation.
\end{abstract}

Keywords: Covid-19, Election, Indonesia, medical and legal measures.

\section{Introduction}

Covid-19 pandemic is now sweeping the world. This virus initially known in Wuhan, China. After that spread very quickly to various countries in the world, including Indonesia. The World Health Organization (WHO) establishes the Covid-19 as a world pandemic. As a result of this pandemic, Indonesia delayed regional head elections which were originally held on September 23, 2020 to December 9, 2020. Given that the pandemic has not ended yet, in the implementation of the elections a health protocol policy was implemented to break the chain of the spread of the covid-19 virus. These policies include the use of masks, hand sanitizer, the application of physical distancing, social distancing and the use of personal protective equipment.

Local elections that will be held in Indonesia are direct local elections. Inevitably the direct local election is an extension of the political participation

\section{Corresponding Author:}

Sri Wahyu Ananingsih

Lecturer at Faculty of Law, Diponegoro University, Jl. Prof. Soedarto, Tembalang, Semarang, Central Java 50275, Indonesia e-mail: sriwahyuananingsih.undip@gmail.com of the people in order to determine the figure of the regional head. Direct elections are also a form of people's sovereignty in order to be elected regional heads who have strong political legitimacy ${ }^{1}$. It is said to have strong legitimacy because candidates are elected directly by the constituents in their area. So thus the elected regional head is expected to be oriented to the welfare of the people in his area $^{2}$. The decision of the Indonesian government to carry out the elections on December 9, 2020 is final, while the covid-19 pandemic is estimated not to end until the end of 2020. Given these conditions for the first time experienced by Indonesia, it is interesting to study the potential for vulnerability that occurred in the 2020 elections. With known potential vulnerability, prevention efforts can be made so that no alleged violations occur.

\section{Method}

This study was designed as a descriptive qualitative research focusing on examining the potential for 2020 elections in the midst of the Covid-19 pandemic in Indonesia. Qualitative approach is an approach that provides an opportunity for researchers to describe and interpret research results in order to obtain a comprehensive understanding ${ }^{3}$. This research was conducted in Indonesia where as many as 270 regions consisting of 9 provinces, 224 districts, and 37 cities 
will carry out the elections on December 9, 2020. All qualitative data includes primary data and secondary data. Primary data obtained through interviews and interactive discussions. While other data in the form of secondary data obtained from literature studies, in the form of references from journals as well as research results and legislation related to regional head elections. All data were analyzed using descriptive method.

Implementation of the 2020 Elections in Pandemic Covid-19: Indonesia is not the only country to hold elections in the midst of the 19th pandemic. There are about 15 countries in the world that will also hold elections in the period June to November 2020. These countries include Mongolia, Iceland, Tanzania, Jordan, Australia, Malaysia and the United States (MDN News Magazines, Impact on elections International IDEA Stockholm, MDN News Magazine Special Edition 01/ $\mathrm{VI} / 2020)^{4}$. In Indonesia itself, it will simultaneously hold regional head elections (elections in 270 regions covering 9 provinces, 224 districts and 37 cities).Based on the graphic info data above, the 5 provinces that hold the most regional elections are North Sumatra Province (23 Regencies/Cities), Central Java Province (21 Regencies/Cities), East Java Province (19 Regencies/ Cities), West Sumatra Province (14 Regency/City) and South Sulawesi Province (12 Regency/City).

The decision of the Indonesian government to hold elections in 2020 one of them is due to the consideration that around 200 incumbent regional heads participating in the 2020 elections (from 270 regions) will end their term of office on February 17, 2021. So if the regional head election is delayed until the year 2021 , it is feared that it will disrupt the running of the regional government, especially in the 200 regions. Therefore, in 2021, the position of regional head has ended and was replaced by an tasks executor official. The official has limited authority and does not cover the authority to decide on strategic matters, aka the government decides on the implementation of the elections in 2020 despite the Covid-19 pandemic.

Considering that Indonesia has only once held a regional election in the midst of a Covid-19 pandemic, it is interesting to study the potential vulnerability that might occur in the 2020 elections. The first potential for vulnerability is the issue of budget availability. The budget for this year's elections is needed by organizers not only to finance the elections but also to meet the needs of procurement of medical devices. The problem was that medical equipment had not been budgeted by the election organizers at that time because at the time of budgeting there was no Covid-19. An additional budget is needed for that. The fact is that most regions are no longer able to provide additional funding for the procurement of medical devices. This is due to the local government's budget allocation has been focused on financing the Covid-19 pandemic countermeasures. To overcome these conditions, efforts were made to partially provide the budget by the central government through the Indonesian State Budget and partly through restructuring the existing organizers' budgets, and some budgets have been returned to the government to support efforts to overcome the Covid-19 pandemic. As for the needs of medical devices such as masks, hand sanitizers, and soaps, specifically for areas that are prone to covid-19, face fields and personal protective equipment (PPE) are also needed.

The budget is also needed by the General Election Commission (KPU) for the costs of organizing regional head elections. An urgent budget beyond what already exists is a budget for the cost of adding to the number of polling stations. This is because the KPU reduced the capacity of the number of voters in each polling station so that the polling stations grew. Per polling stations, from a capacity of 800 people reduced to 500 people, reduction in the capacity of voters per stationsin order to prevent the spread of covid-19. Due to the addition of polling stations, the number of polling station officers and supervisors has increased. In addition to the KPU, the Election Supervisory Body (Bawaslu) also requires a budget for the costs of adding supervisors.

Another budget needed by the organizer is the cost of strengthening the internet network to support smoothness at each stage of the regional head election. KPU Regulation No.5 of 2020 states that some stages can be carried out using internet information technology, although it is recognized that not all regions have easy access to the internet network, such as islands or mountainous regions such as Papua and Maluku. If it is not reached by the internet, the regional head election process must be carried out as in the regional head election in normal conditions with strict health protocols to prevent covid-19.

The readiness of the regional head election is the potential for a second vulnerability. The election of regional heads in the midst of the Covid-19 disaster is a new thing that has never happened before, even though 
the organizer in carrying out its main tasks functions is required to hold on to 5 principles namely: independent, impartial, transparency, professional and sustainability (United Nation Development Program, Principles for Independent and Sustainable Electoral Management, International Standard for Electoral Management Bodies, Cairo, Egyp, 9-11 April 2012)5. Organizers are also said to be election law enforcement officers, so in the context of building an electoral law enforcement system, the effectiveness of the performance of election administrators as election law enforcement officers has an important role ${ }^{6}$.

In Covid-19 conditions, the organizer's readiness includes readiness to always maintain the health of oneself and the community. The health protocol from the government must be applied strictly. Apart from that, the provision of knowledge for the implementation of the performance of the organizers plays an important role. In this election the provision of knowledge can be done virtually through online media. Many online service provider applications can now be used such as Whats App, Zoom Meeting, Facetime, Microsoft Team and so on. This effort was made to save the budget and also to prevent the spread of covid-19.

Other organizers' readiness is in the form of providing regulations that are adjusted to the conditions of the Covid-19 pandemic. According to the International Institute for Democracy and Electoral Assistance (IDEA), free and fair elections require the availability of legal instruments governing each stage of the election ${ }^{7,8}$. In accordance with the covid-19 protocol, regulations must regulate restrictions on activities that are mass gathering/supporters. Instead, alternative method are given such as activities through online media/internet. For example, at the stage of updating voter data that began on July 6, 2020, the process of matching voter data, recapitulation and announcement of the voter list which in the previous election was carried out by face to face/physical meeting then in the 2020 elections can be done using online/online media.

Likewise, at the campaign stage carried out on September 26 to December 5, 2020. Participants in the regional head election can carry out campaign forms such as limited meetings, face-to-face/dialogue meetings, public debates, installation of campaign props, media advertisements and forms others that do not violate laws and regulations. The KPU also provides time for regional head election participants to carry out campaigns through mass, print and electronic media from November 22 to December 5, 2020. The form of face-to-face meetings, dialogues and limited meetings has special arrangements such as place, number of campaign participants, campaign time, and compliance with government health protocol requirements.

At the stage of voting and counting, it is necessary to arrange for a representative polling place. In the provisions of Article 87 of Law No.10/2016, each polling station has a maximum voter capacity of 800 people, but because of Covid-19, the KPU rearranges the capacity of 500 voters in each polling station his. Likewise, it is also related to the facilities that need to be provided in polling stations including the provision of hand washing facilities, soap, hand sanitizers, and masks. The queuing system for voters who will use their voting rights must also be set at least 1 meter apart. In areas prone to Covid-19, organizers must be equipped with personal protective equipment in accordance with government protocol. In the recapitulation stage of vote counting, it can be done by the online media method.

With regard to the supervision of each stage of the election, it is the authority of the Bawaslu. In conducting surveillance, Bawaslu must apply health protocol standards from the government. Bawaslu's steps in preparation for the supervision of regional head elections 2020 based on Bawaslu Circular No.0298/K.Bawaslu/ PM.00.00/5/2020 is to prepare for the supervision of the stages of regional head election (Election) to identify the obstacles in the implementation of elections and ensuring health protocols for election observers when conducting surveillance. Furthermore, the Bawaslu issued Bawaslu Circular Letter No.0351/K.Bawaslu/PM.00.00/6/2020 concerning the implementation of election supervision during the covid-19 pandemic. Regarding the handling of violations, Bawaslu must have a specific strategy in processing every alleged violation whether it is an administrative violation, a code of ethics or a criminal election as well as in exercising the authority to handle disputes over the election process.

The third potential vulnerability is the number of alleged violations that occurred during the regional head election. This potential vulnerability is likely to arise due to conditions affected covid-19, for example the stages that are usually carried out in physical meetings or face to face now turn to virtual. This can result in the stages not running optimally, the level of compliance of the organizers with the covid-19 protocol 
and alleged violations committed by participants in the elections. Alleged violations that are expected to occur include alleged abuse of authority, vote buying, black campaigns, campaign violations on social media and also the neutrality of the civil servants.Furthermore, allegations of campaign violations on social media are expected to increase compared to the 2019 elections. This estimate arises because of restrictions on campaign activities that are mass gathering or physical gatherings. These restrictions are carried out in accordance with the recommendations of the Covid-19 health protocol from the government. Instead, campaign activities can be carried out using internet media/online. This will later encourage increased use of social media in the 2020 elections. Moreover, the cost of using social media campaigns is cheaper than campaigns using mass media ${ }^{9}$.

Regarding the alleged violation of the neutrality of the civil servants, this alleged violation has been rife since the start of the 2020 elections until now. This violation is prone to occur in areas where the incumbent regional head is running again. With his power, the incumbent head easily mobilized civil servants to support his candidacy. Meanwhile, Law No. 5 of 2014 concerning civil servantsand alsoGov. Reg No.42/2004 explicitly explained that civil servants must be neutral, impartial and impartial, but in practice many civil servants committed violations. Bawaslu recorded in the 2020 regional head elections there were 342 suspected cases of violation of civil servants neutrality as of June 19, 2020.

The fourth potential vulnerability is community participation. Participation in this case includes not only participation in exercising their voting rights but also actively participating in each stage of the election. For example, in the factual verification stage for individual candidate pairs, residents who support the candidate pairs are willing to be met by the verification team of the KPU, or at the voter data update stage, active citizens check and re-check whether they are registered on the voter list; residents are also expected to actively participate in conducting participatory supervision at each stage and report suspected violations.

Under normal conditions, several things that cause a low level of community participation in the elections are the distrust of the community towards the candidate pair, the disinterest with the candidate and the perceived lack of benefits from the elections ${ }^{10}$. In the covid-19 pandemic situation there is a possible cause for the decline in the level of community participation due to the concern/fear of the danger of covid-19 transmission.For this reason, the government and election organizers must actively disseminate information to the public on the importance of community participation. Without the participation of the community, there will be no regional head election with integrity and fair. In addition to the criteria for public participation, elections with integrity and fairness must meet the criteria of equality between citizens, legal certainty, free and fair competition between election contestants, professional, impartial and independent organizing institutions, integrity of collection and vote counting and fair and timely resolution of election disputes $^{11}$.

\section{Conclusion}

Indonesia will hold a regional head election 2020 in the midst of Covid-19 pandemic. There are 270 regions holding regional elections this year, consisting of 9 provinces, 224 districts and 37 cities. The voting itself will be held on December 9, 2020. Potential vulnerability in the regional head election this time includes 4 potential namely availability of budget, readiness of election organizers, the emergence of many allegations of violations and public participation. Recommendations from this study are collaborative efforts, coordination, and communication between the government and election administrators. In addition to increasing public participation is also needed so that the election of regional heads 2020 in Indonesia is quality and fair.

Ethical Clearance: This research was ethically approved by Faculty of Law, Universitas Diponegoro, Semarang, Indonesia

Funding: The research was financially funded by Faculty of Law, Diponegoro Universityfrom the 2020 fiscal year.

Conflict of Interests: There are no conflict of interests

\section{References}

1. Simamora J. Eksistensipemilukadadalamrangkamewujudkanpemerintahandaerah yang demokratis. Mimbar Hukum-Fakultas Hukum Universitas Gadjah Mada. 2011;23(1):221-36..

2. Nuryanti S. Intervensipenyelenggaraanpemilukada: 

regulasi, sumberdaya dan eksekusi. JurnalIlmu Sosial dan IlmuPolitik. 2015;19(2):125-40.

3. Lincoln YS, Denzin NK, editors. Handbook of qualitative research. Sage; 1994.

4. MDN News Magazines, Impact on elections International IDEA Stockholm, MDN News Magazine 1 June; 2020.

5. United Nation Development Program, Principles for Independent and Sustainable Electoral Management, International Standard for Electoral Management Bodies, Cairo, Egypt, 9-11 April 2012.

6. Santoso T. Penegakan Hukum Pemilu; Praktik Pemilu 2004. Tim Peneliti Perdulem; 2006.

7. IDEA Internasional. Standar-Standar Internasional Pemilihan Umum: Pedoman Peninjauan Kembali
Kerangka Hukum Pemilu. Jakarta: Internasional IDEA; 2004.

8. Goodwin-Gill GS. Free and Fair Election: International Standar and Practices. The Asia Foundation; 1999.

9. Saraswati MS. Social media and the political campaign industry in Indonesia. Jurnal Komunikasi Ikatan Sarjana Komunikasi Indonesia. 2018 Jun 12;3(1):51-65.

10. Winengan W. Local Political Democratization Policy: Voter Participation in the Direct Regional Head Elections. JurnalIlmu Sosial dan IlmuPolitik. 2018 Sep 5;22(1):61-73.

11. Surbakti R. Pemilu Berintegritas dan Adil. Harian Kompas 14; 2014. 